University of Nebraska - Lincoln

DigitalCommons@University of Nebraska - Lincoln

Textile Society of America Symposium

Proceedings

Textile Society of America

2020

The Nantucket Looms: Historicism and Modernism in an Island

Cottage Industry

Jennifer Nieling

Follow this and additional works at: https://digitalcommons.unl.edu/tsaconf

Digitalrt of the Art and Materials Conservation Commons, Art Practice Commons, Fashion Design

Commens, Fiber, Textile, and Weaving Arts Commons, Fine Arts Commons, and the Museum Studies

detwerkns

Logo

This Article is brought to you for free and open access by the Textile Society of America at

DigitalCommons@University of Nebraska - Lincoln. It has been accepted for inclusion in Textile Society of America

Symposium Proceedings by an authorized administrator of DigitalCommons@University of Nebraska - Lincoln. 


\section{The Nantucket Looms: Historicism and Modernism in an Island Cottage Industry}

Jennifer Nieling

ilnieling@gmail.com

Nantucket, an island thirty miles off the coast of Cape Cod in Massachusetts, is well known as a time capsule of sorts, seemingly frozen in the era of its glory days as a whaling port, which ended in the mid-nineteenth century. Greek revival mansions, cedar-shingled houses, and quiet sandy beaches render Nantucket an idyllic seasonal retreat for those who can afford it. In the 1960s, the island was transformed into the exclusive high-end destination that we know today, as long-time summer resident Walter Beinecke Jr. bought up and rebuilt the town's waterfront into a picture-perfect gateway to luxury, promoting historical tourism and reinforcing Nantucket's carefully crafted historic image through both commercial and nonprofit ventures. ${ }^{1}$ One of these ventures was the Nantucket Looms. Founded to create reproduction historic textiles, the company evolved to incorporate both the historic knowledge and modern sensibilities and aesthetics of its practitioners. Despite the island's perceived isolation and its preoccupation with its own history, Nantucket was not immune to the zeitgeist of the time. The story of the Nantucket Looms is one of the craft revival of the 1960s, with equal parts historicism and modernism, and with its own unique island flavor.

Research for this paper began back in 2017 when I was Costume and Textile Specialist at the Nantucket Historical Association (NHA). I had the opportunity to collect and catalog several donations of objects related to the Nantucket Looms, including the generous donation of over 100 objects and a wealth of archival materials from Julie Beinecke Stackpole, daughter of Nantucket Looms founder Mary Ann Beinecke. ${ }^{2}$ Fascinated by the many themes and connections in this story of modernism on the historic island of Nantucket, I continued to research the Nantucket Looms' early years, conducting interviews, consulting contemporary press and the newly available archival materials, and of course examining the textiles themselves, many of which are highlighted in this paper. ${ }^{3}$

The Nantucket Looms began under Walter Beinecke's nonprofit Nantucket Historical Trust, established to preserve and restore historically significant sites on the island, and in turn stimulate Nantucket's year-round economy. In 1961, the Trust undertook the restoration of the Ocean House hotel, a three-story brick mansion built in 1845 by wealthy whaling merchant Jared Coffin. The Trust removed the hotel's late Victorian additions and restored the building to its original neoclassical simplicity, in keeping with the historic image of Beinecke's Nantucket. The

\footnotetext{
1 “Walter Beinecke's Fight For Nantucket: Buying up an Island for Its Own Good,” Life, September 6, 1968, Google Books. This article discusses the motivations behind and controversies surrounding Beinecke's activities on Nantucket, which it describes as a "benevolent financial dictatorship."

2 The Stackpole donations to the Nantucket Historical Association (NHA) include objects 2018.11.1-100 and manuscript collections Ms.550, the Mary Ann Beinecke Papers 1963-1975, and Ms.549, the Julie Beinecke Stackpole Collection on Mary Ann Beinecke, 1961-2018. The latter collection includes copies of many of the articles cited in this paper, and a manuscript by Julie Beinecke Stackpole, Mary Ann Beinecke's Nantucket Textile Renaissance, a History and a Memoire, by her daughter (2018), which was an invaluable resource for this study. ${ }^{3}$ Full catalog records including details and images of all the Nantucket Looms-related objects in the NHA collection are available online at https://nha.org/research/the-collections/. Objects referenced but not pictured in this paper are identified by their accession number. Additional objects are referenced in the footnotes.
} 
interiors were elaborately decorated in a historic style that recalled the whaling era, and the mansion was reopened as a luxury and, significantly, year-round hotel named the Jared Coffin House. ${ }^{4}$ The hotel was furnished with actual antiques from the late eighteenth and early nineteenth centuries, and in an aim for authenticity, the interior textiles, of course, had to look historic as well. ${ }^{5}$

Seeing an opportunity to create a craft industry on the island, Mary Ann Beinecke, wife of financier Walter, was determined to produce the textiles on-island, providing year-round work for locals in the process. Mrs. Beinecke was the ideal woman to lead the project, as a historian and talented practitioner of the textile arts, as well as a collector of rare books on textiles and design. She brought in local weaver Andy Oates as head craftsman to train local recruits in handweaving, and together they set up a weaving workshop on Main Street. ${ }^{6}$

Over the next two years, the team of 11 weavers produced over 6,000 yards of textiles for the hotel, including upholstery, draperies, coverlets and bed hangings, as well as carpets and rugs. Samples of several of these textiles, accompanied by color photographs of the hotel interiors, appear in a promotional book that contains the only known extant pieces from the project, as the hotel was later redecorated. The designs were reported to be authentic to the early nineteenth century in color, pattern, and weave, and while both Beinecke and Oates were credited as designers, they took inspiration, and most likely actual patterns, from Mrs. Beinecke's impressive book collection, which now resides in the Clark Art Institute library. ${ }^{7}$ These patterns included herringbone, rugs in a special chenille weave, and a variety of overshot patterns, which represent a long tradition in American textiles, as they are easily diagrammed and passed down over time. Everything was woven in all-natural fibers, chosen with exacting standards by Mrs. Beinecke from suppliers around the world, and custom-dyed to her specifications. ${ }^{8}$

\footnotetext{
${ }^{4}$ For a detailed history of the Jared Coffin House and changes to the building until 1962, see H. Errol Coffin, "The Jared Coffin House, Formerly the Ocean House," Historic Nantucket, April 1962 (copy in Ms.549). The Jared Coffin House restoration and contemporary press that promoted the hotel and island while expressing disdain for post-1860 architecture and (incorrectly) denying its existence on Nantucket were part of a larger effort to downplay Nantucket's post-whaling history and promote and capitalize on the constructed historic image that Beinecke played a large part in creating. See for example "Ruggedness \& Elegance," House \& Garden, April 1966; Marion Gough, "Those Unexpected Pleasures," House Beautiful, November 1964; and Evan Frances, "Classic Colonial, Nantucket Style," Family Circle, May 1966, 50-55 (copies in NHA Ms. 549).

${ }^{5}$ Photographs and descriptions of the hotel's interiors are included in [Melva A. Chesrown], Public relations book for Jared Coffin House and White Elephant, circa 1960s, NHA Ms.550. Many contemporary articles drew on this material, notably Marian Page, "The Jared Coffin House, fifth in Interiors' series on Historic Restorations," Interiors, January 1964, and "Nantucket Renaissance," Interior Design, January 1964 (copies in NHA Ms.549.) ${ }^{6}$ For more on Mary Ann Beinecke and her work with textiles, see Stackpole. Several articles describe the origin story of the weaving workshop, most notably Marilyn Hoffman, "Where Weavers Weave," Christian Science Monitor, October 28, 1964, 5, Proquest.

${ }^{7}$ Stackpole (13) describes how Mrs. Beinecke's research in her collection of eighteenth and nineteenth century textile books was integral to her design process. Digitized records in the collection show many books with weaving diagrams and patterns similar in style and technique to textiles created for the Jared Coffin House. This leads me to suspect that patterns were taken directly from the books, which could be confirmed by further comparison of the books to the textiles in question. "Mary Ann Beinecke Decorative Art Collection," The Clark Art Institute, https://www.clarkart.edu/library/special-collections/mary-ann-beinecke-collection, accessed January 21, 2021. ${ }^{8}$ Promotion book with samples, undated, NHA Ms.550. The textiles are described in detail in Melva A. Chesrown, "Nantucket Looms, Fabrics by Island Weavers in Restored Inn," Handweaver \& Craftsman, Fall 1963, 6-9. Yarns and custom dyeing are mentioned in Hoffman and "Handlooms on Nantucket," American Fabrics, Fall 1965, 21-22.
} 

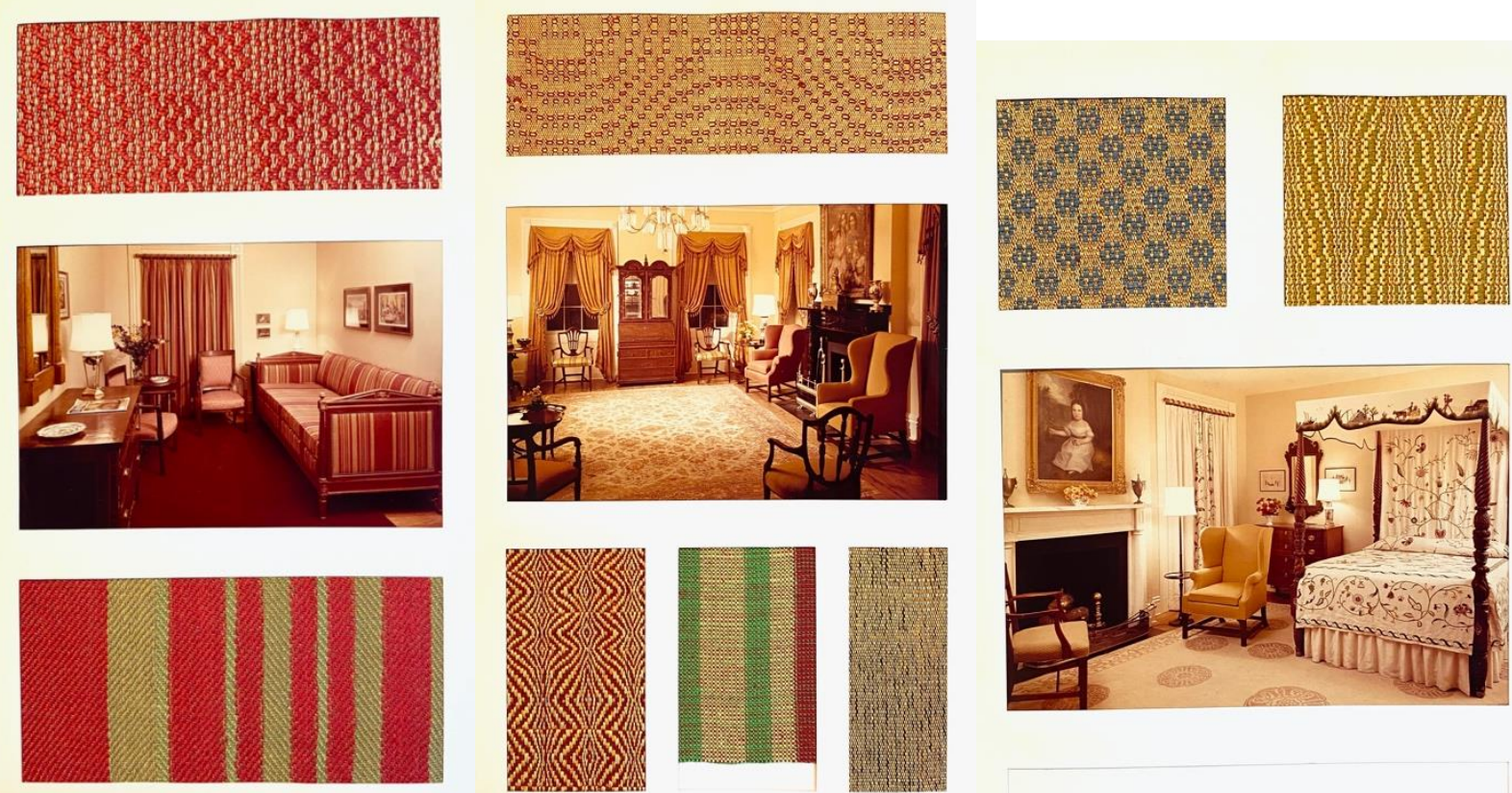

Jared Coffin House interiors and fabric samples, circa 1964: Guest room; lounge, including herringbone silk textile; and "Embroidery Room," including overshot patterned textiles. Promotion book with samples, undated, Mary Ann Beinecke Papers, Nantucket Historical Association. Photos by the author.

Another branch of the Trust known as the Nantucket Needlewomen made crewel work bed hangings for "The Embroidery Room," which were designed by famed needleworker Erica Wilson, and featured island imagery including Nantucket's so-called "Oldest House," another Coffin family landmark. The work of the needlewomen and the development of Mrs. Beinecke's Nantucket School of Needlery is a story unto itself, deserving of its own study. ${ }^{9}$

The Jared Coffin House finally opened in May of 1963, and an extensive PR campaign served not only to promote the historic image of Beinecke's Nantucket and its new hotel, but also prominently featured the new textile venture, officially named the "Nantucket Looms" by that fall. From the onset, Beinecke and Oates had bigger plans for their weavers. As they were completing the textiles for the hotel, they were already working on private commissions, including custom rug orders and the textiles for the Beineckes' own off-season island home, which was decorated in the same style as the hotel. The Nantucket Looms was already gaining a reputation for high-quality hand-woven textiles, and the company was serious about establishing itself as a commercially viable venture. They acquired new and wider looms, advertised their success in maintaining production schedules and performance tests, and even worked with loom manufacturer Macomber to develop a new tool to improve efficiency in production weaving: a special dressing frame that allowed very long warps to be prepared separately from the loom,

\footnotetext{
9 "Ruggedness \& Elegance"; Public relations book for Jared Coffin House and White Elephant. For more on the Nantucket Needlewomen and Mary Ann Beinecke's Nantucket School of Needlework, see Stackpole, 15-17, 33-40; 49-57; 68-79; Ms.549 and Ms.550
} 
then set in when needed. By the new year of 1964, the Nantucket Looms had expanded to the production of sportswear tweeds, offering 125 different options. ${ }^{10}$

Only one year after the Jared Coffin House opened, the Nantucket Looms secured national distribution through Thaibok Fabrics, a New York-based distributor of luxury imported textiles, for whom the Looms designed a completely new line of upholstery and drapery fabrics, including more than two dozen patterns in almost 100 color ways. With this new line came a new focus on the modern market, as they sought to appeal to both traditional and modern design sensibilities. While traditional patterns and aesthetics were still very much a part of the line, described as "classic" and "neotraditional" by The New York Times and "heirlooms of tomorrow" by the Christian Science Monitor, the new designs also aligned with modern ideals of good design, promoted by exhibitions and design competitions of the mid-twentieth century. The fabrics prioritized function and the role of textiles as part of a harmonious whole, with an increased focus on texture and fibers, and a modern interpretation of color. ${ }^{11}$

This transition from traditional to modern is especially evident in the promotional book, which shows several pages of Jared Coffin House textiles and photographs followed by eight new textile designs in bright, clear colors and a variety of textures, each named after a different geographical area of Nantucket. Each textile was offered in several colorways, and many of these used the same warps, again showing that the Looms prioritized workshop efficiency.

\footnotetext{
${ }^{10}$ Chesrown; Hoffman; Promotion book with samples; "Nantucket Weavers Read to Try Their Skills in Many New Areas," Inquirer \& Mirror, January 2, 1964, Nantucket Atheneum's Digital Historic Newspaper Archive [referred to hereafter as Nantucket Atheneum]. Chesrown's article is the first time the "Nantucket Looms" is mentioned in print, and also discusses the Macomber loom collaboration. For more on the Beinecke home (69 Main Street), see Stackpole 17-32. Samples of upholstery fabrics, draperies, and a rug from the Beinecke home now in the NHA collection include 2018.11.2, 2018.11.5a-b, 2018.11.6a-b, 2018.11.13-14, 2018.11.20-22. Photographs of the home are in NHA Ms.549.

11 "Nantucket Historical Trust Announces New Agreement for World-Wide Sale of Island Manufactured Fabrics," Inquirer \& Mirror, May 28, 1964, Nantucket Atheneum; Photograph with press release, NHA Ms.549; Lisa Hammel, "New Line of Fabrics Is Woven on Nantucket," The New York Times, October 16, 1964, Proquest (quoted); Hoffman (quoted); Susan Ward, "The Design, Promotion, and Production of Modern Textiles in the USA, 1940-60," in Knoll Textiles, ed. Earl Martin (New Haven: Published for Bard Graduate Center by Yale University Press, 2011), 36-72.
} 


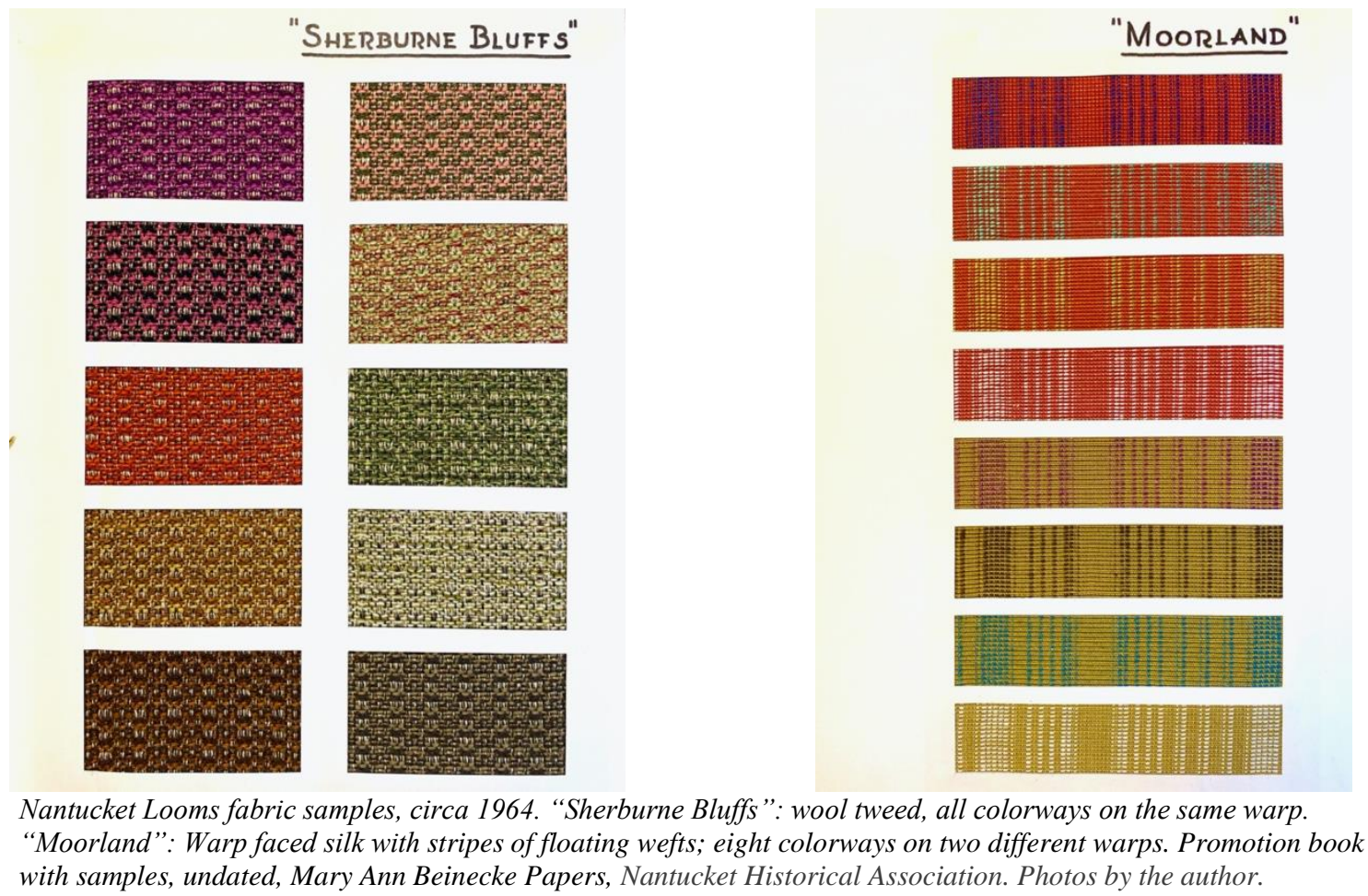

The Nantucket Looms also offered several casement fabrics in their line for Thaibok, which directly attest to the idea of designing for function in a space. Mary Ann Beinecke expressed this idea in a widely distributed Associated Press article in 1965: "What we'd like to do is work with the architects right in the beginning of house planning, so that draperies and other fabrics could be woven for special areas." The author elaborated: "That would mean timeless woven fabrics belonging to the architecture, capturing light, shadows, offering color that would best enhance the room from every vantage point." This concept was put into practice with a very custom curtain (NHA 2018.11.17) that Mrs. Beinecke designed for her Nantucket summer home: an open weave linen with dense stripes strategically placed to block the brightest rays at sunset - a design which was reportedly quite difficult to execute. ${ }^{12}$

A closer look at Andy Oates' educational background and work reveals a clear modernist influence that manifests in his focus on texture, fiber and color. After two years at the Rhode Island School of Design, Oates trained at the progressive Black Mountain College under Anni Albers, modernist weaver and writer who got her start at the Bauhaus. Anni's husband Josef taught principles of design and headed the art department at the college. ${ }^{13}$

\footnotetext{
${ }^{12}$ Vivian Brown (Associated Press), "Handcrafted look big in new American homes," Chippewa Falls, Wis: HeraldTelegram, April 23, 1965. This article was reprinted in several newspapers, as evidenced by clippings in NHA Ms.549. The curtain is discussed in Stackpole, 33. Samples of casement fabrics in the NHA collection include an off-white linen (2018.11.21) and off-white worsted lacey plaid "Hummock Pond" (2018.11.23), which is also featured in photos and a press release in NHA Ms.549.

13 "An Interview with Andy Oates," interview by Connie Bostic, Black Mountain College Museum + Arts Center, Asheville, NC, July 28, 2010, video, 6:02, https://www.blackmountaincollege.org/oral-histories/; Katie Lee Koven, Black Mountain College: Shaping Craft + Design (Asheville, NC: Black Mountain College Museum + Arts Center, 2013), 8-10.
} 
The deep consideration of materials and their role in design was central to Black Mount College's approach, and Anni Albers encouraged experimentation with materials in weaving. ${ }^{14}$ Early Looms fabrics show Oates to be a disciple of his teacher, as a variety of materials give texture and dimension to his designs. Mohair throws and shawls with accents of velvet ribbons quickly became a trademark of the Looms, and were even made into "hostess skirts," at the request of customers. In 1965, a feature in American Fabrics celebrated the impressive range and unique yarns of Nantucket Looms textiles, including one of suede and velvet ribbons, and another of flax and jute, as well as more subtly textured fabrics like a simple nubbed cotton. ${ }^{15} \mathrm{~A}$ length of patchwork fabric that was sold as yardage, probably made later out of remnants and old stock, features 20 different examples of early Looms textiles, including at least one that appears to match a Jared Coffin House fabric sample. Woven with a variety of silk and wool yarns of different weight, texture and twist, the textiles also incorporate an unusual red monofilamenttype yarn, and a blue wrapped silk. The creation of the patchwork itself shows careful composition of color and texture, and is also very much of its time, as patchwork was a big part of the greater craft revival.

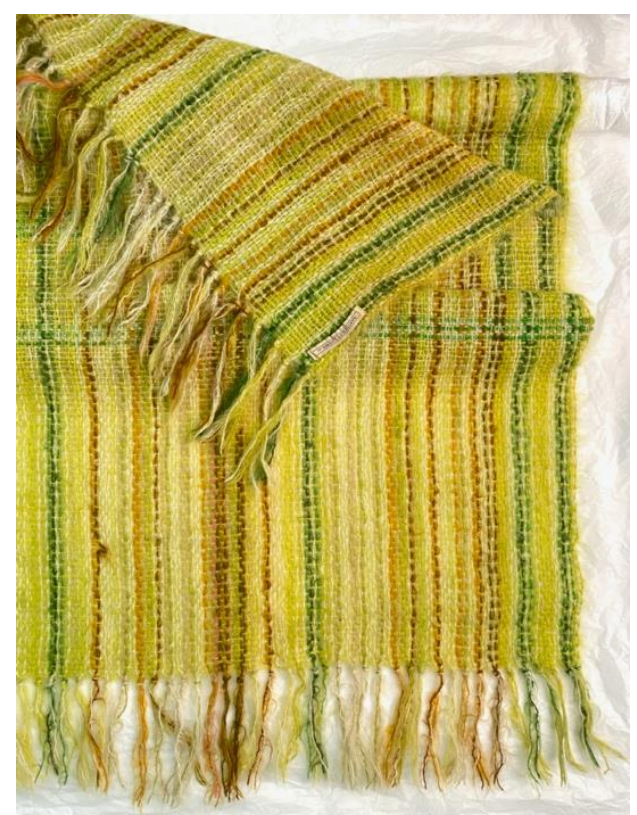

Mohair throw with velvet ribbons. Nantucket Looms, late 1960s to early 1970s. NHA 2018.11.15.

Photo by the author.

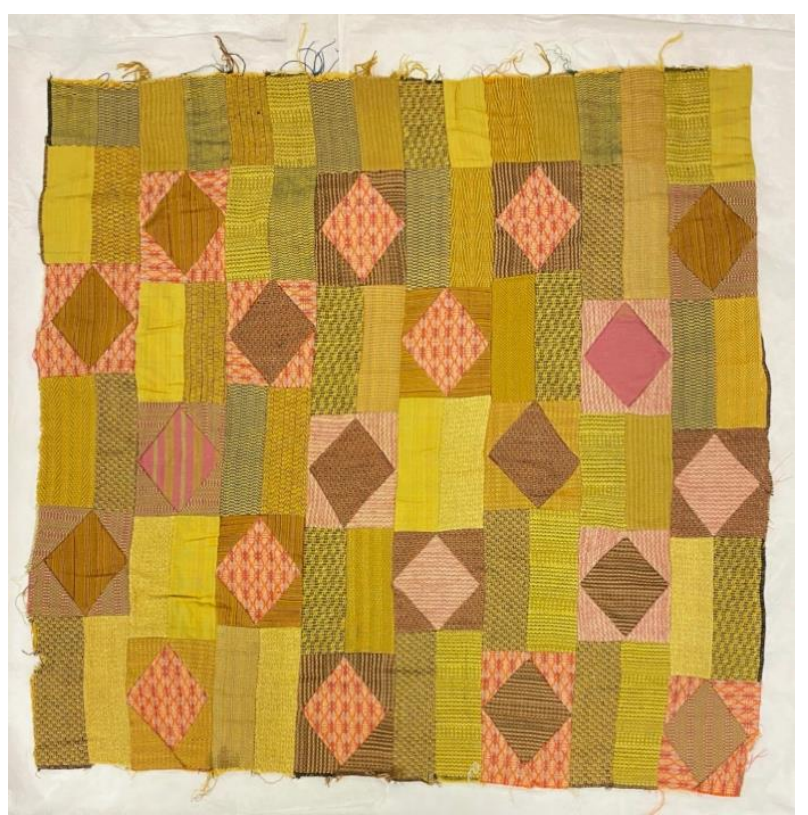

Patchwork made from early Nantucket Looms fabrics, 1960s. NHA 2018.11.1. Photo by the author.

Oates would have been exposed to Josef Albers' color theory, the concept that colors are perceived in relation to those around them, and Mrs. Beinecke, too, was deeply interested in the study of color. ${ }^{16}$ Many early Looms fabrics show an understanding of the interaction of colors,

\footnotetext{
${ }^{14}$ Koven, 11, 14; Briony Fer, "Black Mountain College Exercises," in Anni Albers, ed. Ann Coxon, Briony Fer, and Maria Müller-Schareck (New Haven: Yale University Press, 2018), 65-67.

${ }^{15}$ Lia Marks (seamstress and clothing designer to the Nantucket Looms) and Karin Sheppard (her daughter, weaver formerly at the Nantucket Looms) in conversation with the author, January 29, 2018; "Handlooms on Nantucket." Nantucket Looms mohair pieces in the NHA collection (not pictured) include skirt 2010.5.1, sample 2018.11.16, and shawl 2018.11.17.

16 "Interaction of Color," The Josef and Anni Albers Foundation, accessed January 18, 2021, https://albersfoundation.org/teaching/josef-albers/interaction-of-color/publications/; Stackpole, 49-50.
} 
artfully blending different shades to create an overall effect, such as using different colored wefts that peep through the warp-faced textile "Sunset Hill," or creating different effects on the same warp with one or multiple weft colors.. The seemingly random patterns of different colored warps in "Coatue" come closer to the organic approach of "creating at the loom" that Albers encouraged, as opposed to rigid overshot patterns. ${ }^{17}$
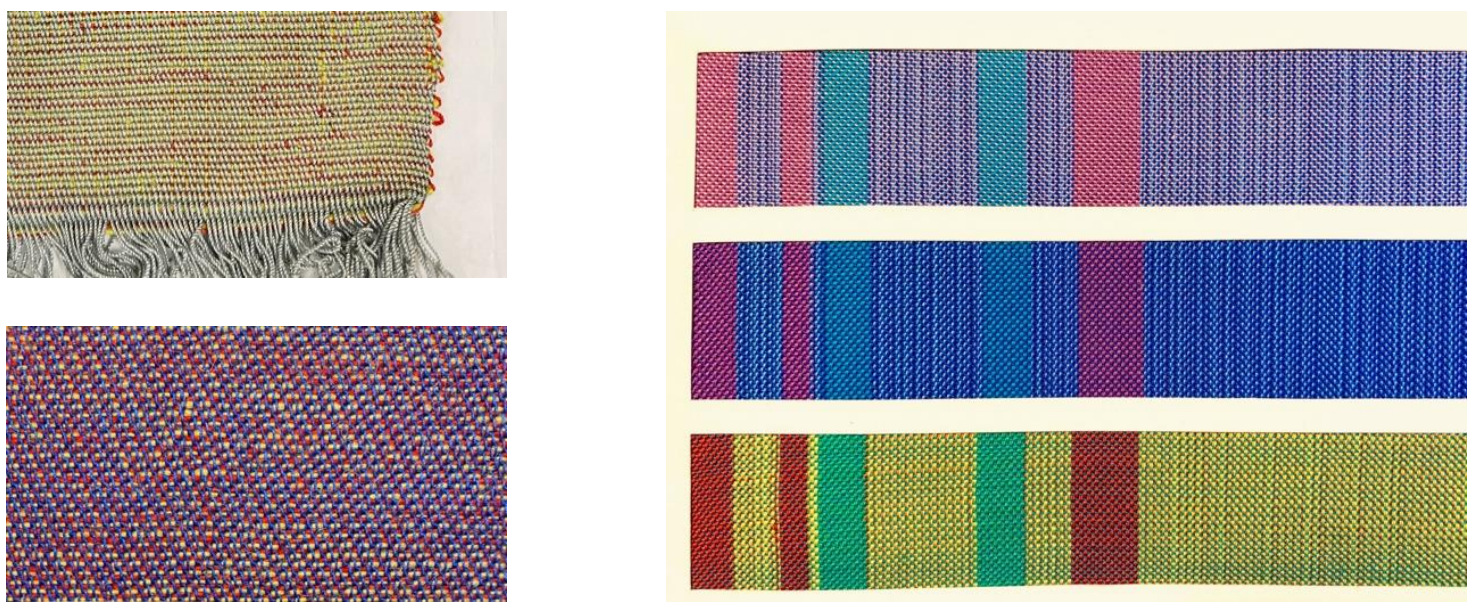

Closeups of Nantucket Looms silk fabric samples, circa 1965. Top Left: "Sunset Hill," light blue warp with green and red wefts, NHA 2018.11.3; Bottom left: "Dionis", blue warp and yellow and red wefts; Right: "Coatue." Promotion book with samples, undated, Mary Ann Beinecke Papers, Nantucket Historical Association. Photos by the author.

One unique piece, a wall hanging, shows a clear influence of geometric abstraction in the style of Anni Albers' work, as well as an adept handling of color. It is a double weave, with two colors of warps threaded to create three columns, and wefts of bundled yarns in different combinations of two shades of green, blue, white, and gold alternating to form rectangular segments.
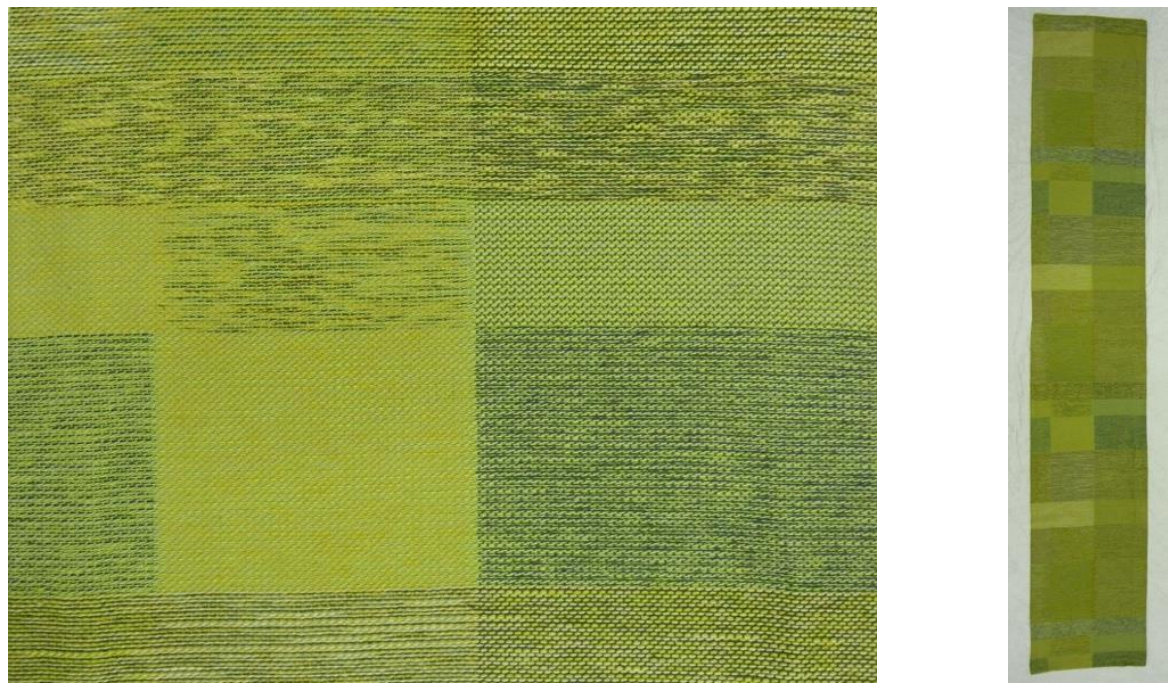

Detail and full length view, Wall hanging, cotton. Nantucket Looms, circa 1964. 73" x 13”. NHA 2018.11.11. Photos by the author.

\footnotetext{
${ }^{17}$ Virginia Gardner Troy, The Modernist Textile: Europe and America, 1890-1940 (Aldershot: Lund Humphries, 2006), 156-157.
} 
In keeping with the values of the greater craft revival, the Nantucket Looms had liberal philosophies around systems of work and was dedicated to education and the community. Like William Morris and his arts and crafts movement of the late-nineteenth century, Mary Ann Beinecke strongly believed in the value of handcrafts and a guild system of craftspeople passing down the skills of their trade to apprentices. Also like Morris, the Looms prioritized a pleasant work environment with an airy workshop filled with light, and flexible hours to accommodate the weavers' home lives, fostering a culture of creativity and openness, and a social space where locals often dropped in to chat. ${ }^{18}$

The Looms actively worked to revive and promote handcraft and serve its community, both through showcasing and selling a variety of goods made by local artisans, and also through organizing various educational initiatives. The most extensive program was in embroidery, which became the Nantucket School of Needlery, and they also offered classes in weaving, knitting, and, significantly, screen printing, which they hoped to expand upon as part of their commercial venture. ${ }^{19}$

As the company became more successful and planned for further growth, it came time for the Nantucket Looms to separate from the nonprofit Historical Trust and to seek out new collaborators to build up the print side of the business. ${ }^{20}$ Beinecke and Oates found partners who shared their work and design philosophies and dedication to handcraft in print designers Leslie and D.D. Tillett, who would create an incredible range of printed textiles that drew upon the local history and landscape and combined traditional and innovative techniques, promoting Nantucket's historical image in a completely new way.

By the time the Nantucket Looms invited the Tilletts to the island, the husband and wife team had 20 years of experience and were operating a successful screen-printing workshop out of their home in New York City. As the fifth generation in a family of textile workers, Leslie brought technical skill and unbounded creativity, which was complemented by D.D.'s innate aesthetic sense and training in modern design. The couple was already well-known for their colorful screen-printed designs, popular with the upper crust of American society like Jackie Kennedy and Babe Paley. ${ }^{21}$ In the fall of 1965, the inventories of the Nantucket Looms were officially sold to the Tilletts, most likely financed by Walter Beinecke, and the Looms became the Cloth Company of Nantucket. ${ }^{22}$

\footnotetext{
${ }^{18}$ Stackpole, 6; Linda Parry, William Morris Textiles (London: V\&A Publishing, 2013), 10-11; Chesrown; "Nantucket Renaissance"; Stackpole, 11-13.

19 "Nantucket Weavers Read to Try Their Skills in Many New Areas"; "Travel \& Study: Nantucket Looms.” Craft Horizons, May 1, 1965 (copy in NHA Ms.549).

20 "New York Outfit Takes Over Looms," Inquirer \& Mirror, October 28, 1965, Nantucket Atheneum.

${ }^{21}$ Jennifer Pronesti, The Textile Designs of D.D. and Leslie Tillett, 1947-1979 (MA Qualifying Paper, Fashion Institute of Technology, 2019), Proquest.

${ }^{22}$ While the Inquirer and Mirror reported that D.D. and Leslie Tillett "acquired the assets of the Nantucket Looms" ("New York Outfit Takes Over Looms"), both Stackpole and Seth Tillett questioned the Tilletts' reported ownership of the Cloth Company, and shared the recollection that Walter Beinecke still very much controlled the business and encouraged and funded its expansion. This leads me to believe that the Tilletts were owners in name only, and Beinecke was financial backer. No records have yet been located to clarify the business arrangement. Stackpole, 53; Seth Tillett (son of Leslie and D.D. Tillett) in conversation with the author, August 10, 2020.
} 
It was not hard for the Tilletts to find inspiration on Nantucket, and they engaged deeply with their subject, interpreting island-specific motifs into modern prints. Expeditions with a local horticulturist resulted in the Nantucket Wildflower print, composed of 27 different local wildflowers, and visits to the cranberry bogs inspired the Nantucket Cranberries print. Other prints inspired by the local surroundings included a print cobblestone print, made from a photo of a street in town, and a print of cedar shingles, which was pictured in the New York Times. ${ }^{23}$
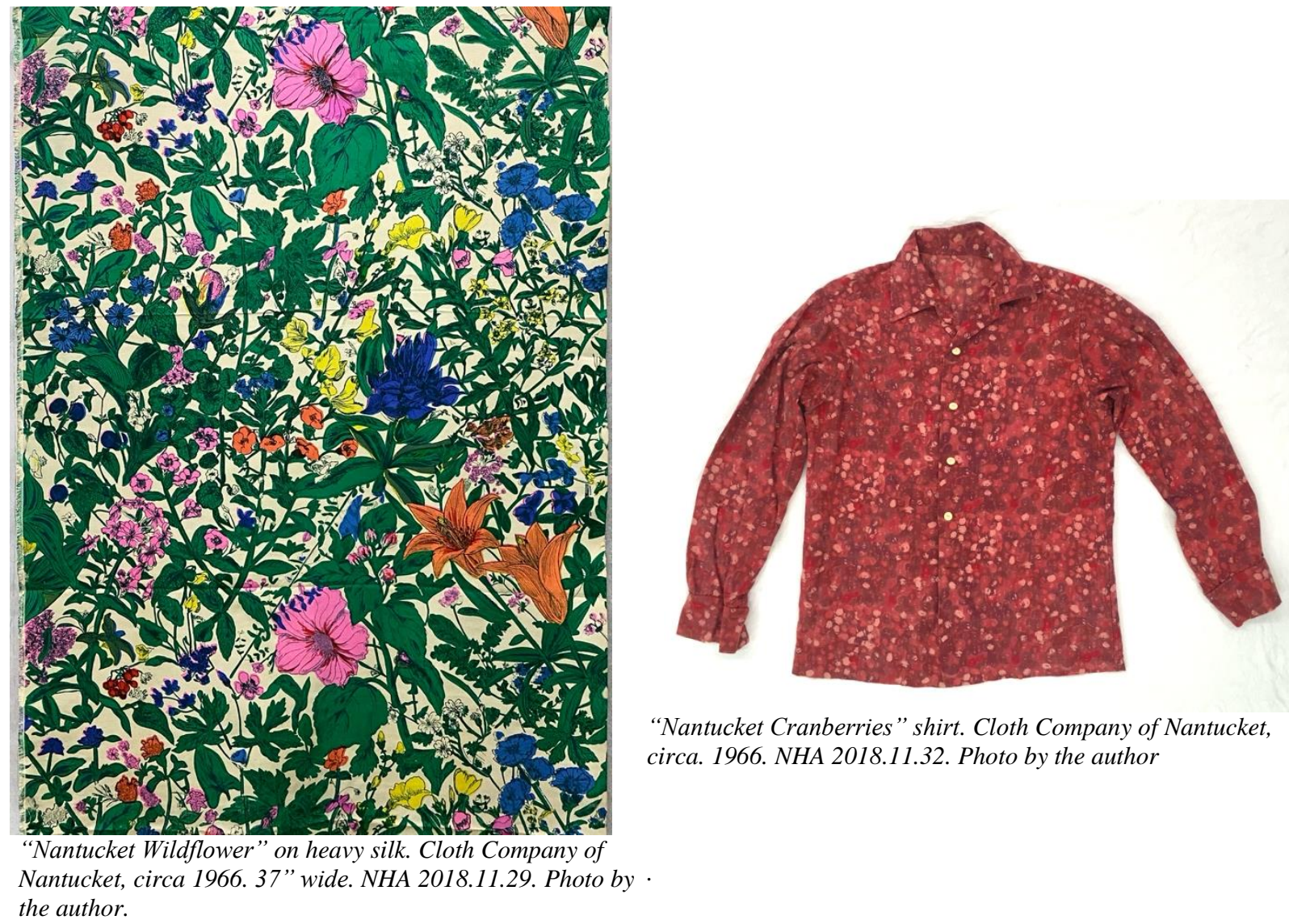

"Nantucket Cranberries" shirt. Cloth Company of Nantucket, circa. 1966. NHA 2018.11.32. Photo by the author

Nantucket's whaling history was also a fount of inspiration, including actual artifacts from the NHA's Whaling Museum, most notably scrimshaw (the art of engraving on whale's teeth and bones), which Leslie enthusiastically took up as a hobby. One particularly striking print, seen below on a silk scarf, faithfully reproduces the imagery of three engraved whale's teeth from the NHA's scrimshaw collection. The Tilletts also designed prints with whaling scenes, ship gear, and of course several prints featuring whales, including a whale paisley that infused a traditional

\footnotetext{
${ }^{23}$ Margaret Yates, “Summer Seasoning," Inquirer \& Mirror, August 4, 1966, Nantucket Atheneum; Stackpole, 4547; Lisa Hammel, “The Nantucket Mood - in Fabric,” The New York Times, July 23, 1966, 37, Proquest. The wildflower and cranberry prints were particularly popular and were printed in various colorways on silks, cottons, and wools. Examples not pictured now in the NHA collection include a shirt of a small scale "Nantucket wildflower" print on wool challis (2018.4.1), a Nantucket Wildflower test print on canvas (2018.11.27), and a sample of "Nantucket Cranberries" in shades of red and green on cotton (2018.11.34). Additional examples of cranberry and wildflower prints and a shirt with the cobblestone print exist in a private collection.
} 
pattern with modern whimsy, and was pictured in both The New York Times and Home Furnishings Daily. ${ }^{24}$

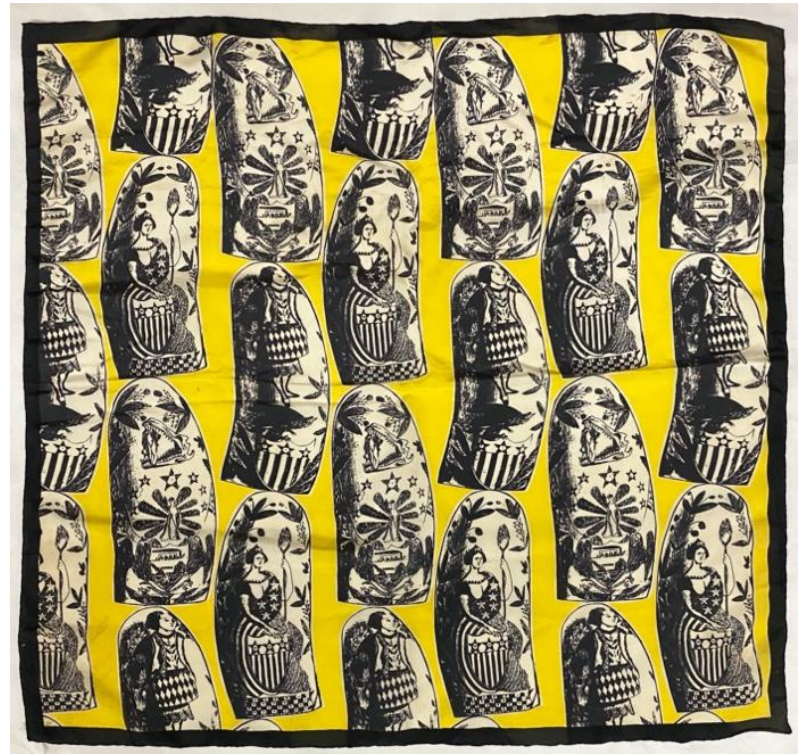

Screen printed silk scarf featuring scrimshaw from the NHA collection. Cloth Company of Nantucket, circa 1966 NHA 2018.11.37. Photo by the author.

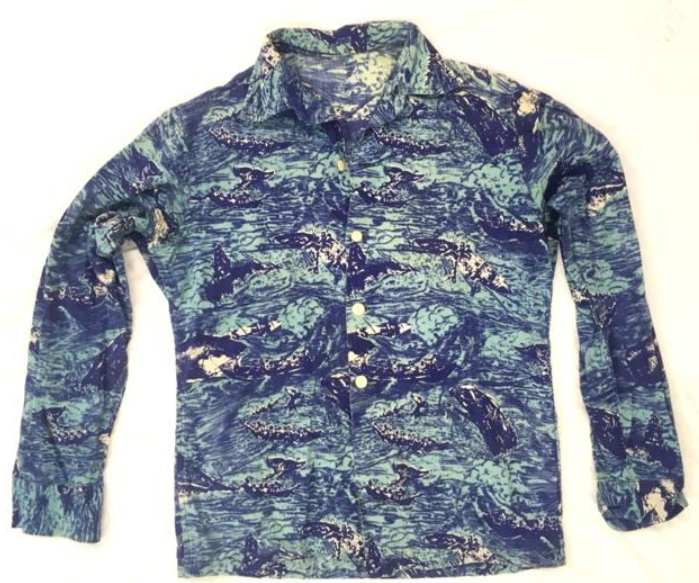

Shirt printed with a whaling scene, cotton. Cloth Company of Nantucket, circa 1966 NHA 2018.11.30. Photo by the author.

The Tilletts printed textiles in a variety of techniques, revealing a deep knowledge of textile history while also innovating new approaches. They experimented with combining screen printing with wax resist Batik, a traditional Javanese technique that Leslie described as "Older than Buddha." A dress sewn by Mary Ann Beinecke from Cloth Company of Nantucket fabric features the Nantucket Wildflower design printed in wax resist on silk with hand in-painting. In her memoir, Julie Beinecke Stackpole, Beinecke's daughter, recalls assisting in the creation of this fabric as a summer intern at the Cloth Company. As the process was very time-consuming and labor-intensive, it is not thought to have been put into production, making the few extant pieces quite unique. The Tilletts also did warp printing, a technique popular in eighteent century Europe, which they claimed (incorrectly) had never been done in the U.S. before the Tilletts did it on Nantucket. ${ }^{25}$

\footnotetext{
${ }^{24}$ Seth Tillett in conversation with the author. Several articles describe the Tilletts' textiles and whaling museum inspirations, notably Yates, "Summer Seasoning," and Hammel, "“The Nantucket Mood - in Fabric." The whale paisley is pictured in Hammel, "A Fashionable Hint of the Sea Floats in From Nantucket," New York Times, November 11, 1967, Proquest, and Charles Kriebel, "Nantucket Catch," Home Furnishings Daily, August 25, 1967 (copy in NHA Ms.549). Other Cloth Company textiles that feature scrimshaw and whaling motifs now in the NHA collection include 2005.10.1-3 and 2018.4.3. Several variations of whale prints also exist in a private collection.

${ }^{25}$ Yates, "Summer Seasoning" (quoted); Stackpole, 47; Seth Tillett in conversation with the author; Hammel, "The Nantucket Mood - in Fabric"; "Cloth Company Owner Introduces a "First," Inquirer \& Mirror, December 30, 1965, Nantucket Atheneum. A search for "warp print" in the database of the National Museum of American History shows several warp-printed textiles produced in the United States in the 1910s and 1920s.
} 


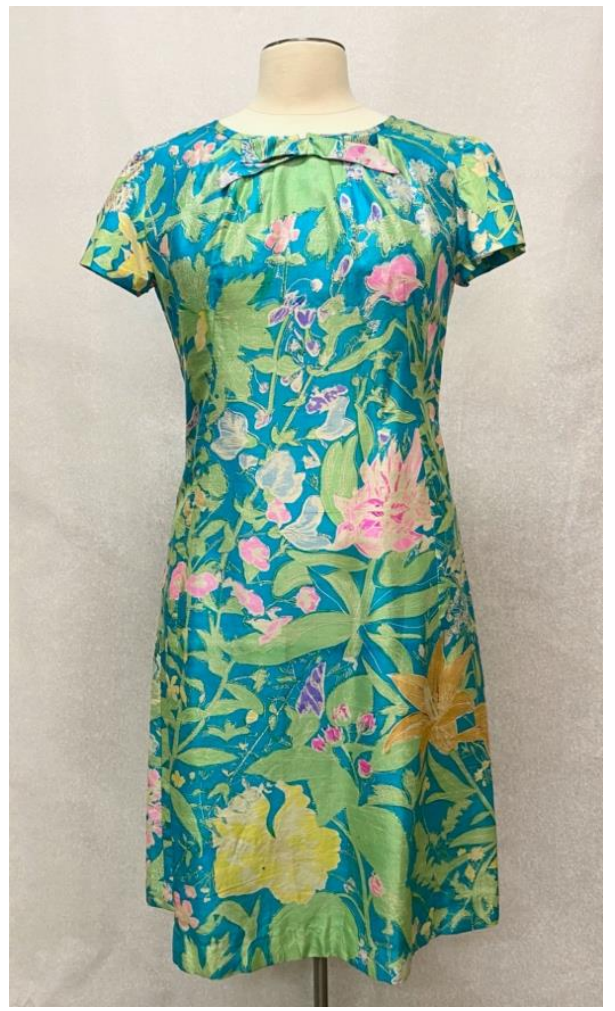

Dress made by Mary Anne Beinecke. "Nantucket Wildflower" print, wax resist on silk with hand inpainting, designed by Leslie and D.D. Tillet for the Cloth Company of Nantucket, circa 1966. NHA 2018.11.28. Photo by the author.

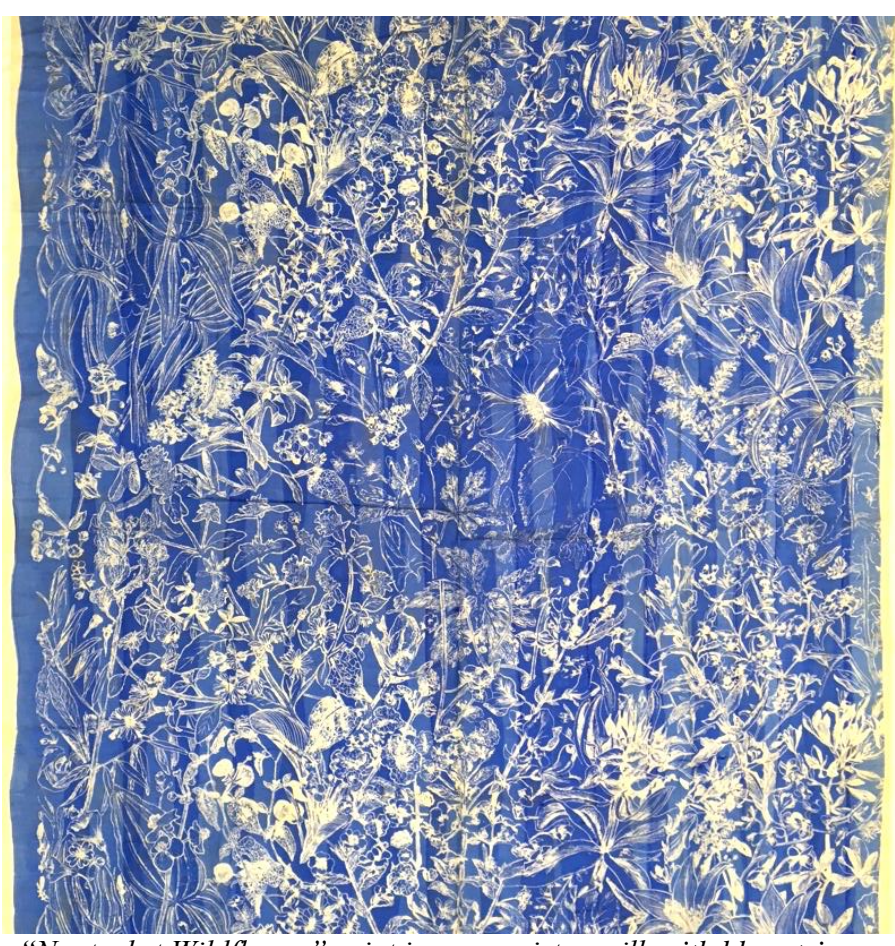

"Nantucket Wildflower" print in wax resist on silk with blue stripes. Cloth Company of Nantucket, circa 1966. 49” wide. NHA 2018.11.26. Photo by the author.

The signature Tillett printing technique was creating stripes or strié effects with their specially developed striation can This device released dye as it was pulled across the fabric, producing stripes of different widths and intervals where slits were cut in the can allowed more dye to be released. Stripes are used in combination with wax resist in the silk above, which was created by hand-brushing blue dye over a wax printed silk, overlapping the lines to create lighter and darker stripes. Several other Cloth Company of Nantucket textiles feature stripes and more subtle strié effects in combination with prints of seagulls (as in the shirt 2018.11.31), whales, and seashells. The Tilletts often layered effects to create depth and texture, which was as important to their prints as it was to Andy Oates' wovens. ${ }^{26}$

The Tilletts were well known for their modernist color sensibility - their son Seth recalls that Leslie was greatly influenced by Chevreul's books on color theory, and owned a copy of Josef Albers' Interaction of Color, from which he would cut color samples to match pieces of fabric. Leslie even gave a series of lectures on color theory and design while on Nantucket. In the wildflower print earlier in this paper (2018.11.29), the layering of carefully chosen shades of bright yellow, pink, and blue creates shades of orange and purple. The layering of color adds an overall depth to the textile, enhanced by imperfect registration that reveals each screen-printed

\footnotetext{
${ }^{26}$ Pronesti, 32, 95-97; Stackpole, 47. Additional examples of striped and strié prints with seagulls, seashells, and whales are in a private collection.
} 
layer. The Tilletts, dedicated to doing everything by hand, embraced the imperfections of handmade prints like imperfect registration and not perfectly straight stripes. ${ }^{27}$

The Cloth Company was created with an eye to expansion, and by the summer of 1966, the company had set up multiple shops on Beinecke's waterfront. They sold kites at the toy shop, accessories and knickknacks at their gift shops. Leslie designed everything from whale ivory jewelry and sewing tools to an ice cream counter for the new Sweet Shoppe. As his son Seth recalls fondly, Leslie even designed the cranberry ice cream to go in it. Garments made of the Cloth Company's printed and woven textiles were designed and made to order by island local Lia Marks, who continued to make clothing for the Cloth Company and the Looms for decades. These included popular unisex shirts with real ivory buttons - a hint of luxury and a nod to Nantucket's whaling history (see the shirts above, and 2018.4.1, 2018.11.31, and 2018.11.33). ${ }^{28}$

Andy Oates continued to head the weaving workshop under the Cloth Company, and D.D. Tillett was involved as well, applying her love of stripes and her painterly approach to color to the design of wovens. It seems that Oates, the Tilletts, and to a certain extent Mary Ann Beinecke, who was more involved with needlework by this time, had a fruitful creative relationship, collaborating and expanding upon designs for key pieces like the mohair throws with velvet that continued to be one of the brand's signatures. ${ }^{29}$

Needlework also continued under the Cloth Company, which sold embroidered and needlepointed gifts and screen-printed needlework designs for customers to D.I.Y. at home. They even designed their own line of yarns in "120 clear, unmuddied colors," developed by Mary Ann Beinecke and Leslie Tillett for use at the Nantucket School of Needlery. The rainbow of bright hues, designed in reaction to the drab colored crewel yarns that were available at the time (inspired by the faded fronts of historic embroideries, versus the bright, unfaded backs), can be seen in a sample card of the "Nantucket Twist" yarns, now in the NHA archives. Yarn development became one of Beinecke's primary pursuits, which she continued throughout her long career. ${ }^{30}$

The Cloth Company's expansion culminated in the opening of a storefront on Madison Avenue in New York City in 1967, which closed after only a few months. As quickly as it started, the exponential growth of the Cloth Company ended, and after less than three years on Nantucket, the Tilletts moved on to other projects. In 1968, Andy Oates, along with Bill Euler, his life

\footnotetext{
${ }^{27}$ Seth Tillet in conversation with the author; "Lessons in Color- the School of Needlery." Inquirer \& Mirror, July 6, 1967, Nantucket Atheneum; Pronesti, 97.

${ }^{28}$ Stackpole, 57-63; Seth Tillett in conversation with the author; Lia Marks and Karin Sheppard in conversation with the author; Hammel, "The Nantucket Mood - in Fabric"; "Vogue's Decorating Finds and Ideas for Fashions in Living: The Tilletts at Nantucket... decorating scoop U.S.A,” Vogue, May 1, 1967, 258, Proquest. Related Cloth Company items in the NHA collection include kites (2018.11.45-46), a collapsible canvas bucket (2018.11.40), a bucket hat with berry print (2018.11.39), and ivory belt buckles (2018.11.42-42). Examples of ivory sewing tools and accessories exist in Seth Tillett's personal collection.

${ }^{29}$ Stackpole; Seth Tillett in conversation with the author.

${ }^{30}$ Hammel, "A Fashionable Hint of the Sea Floats in From Nantucket"; "Vogue's Decorating Finds and Ideas for Fashions in Living"; Beth Callahan, "Island Needlework," Boston Sunday Globe, September 25, 1966; "Lessons in Color- the School of Needlery" (quoted). For more on Mary Ann Beinecke's yarn development, see Stackpole 49-53 and NHA Ms.549.
} 
partner and the company's long-time manager, purchased the textile inventories of the business and returned the name to the Nantucket Looms. ${ }^{31}$

Andy Oates continued to run the Looms with the values and design philosophy that he had helped to establish, training new generations of weavers to create high-end traditional and modern textiles for interiors and garments, and selling clothing, gifts, and handcrafts made by local artisans. Oates and Euler created new Nantucket classics like the classy but casual CPO jacket, made of Nantucket Looms tweeds with Liberty of London lining and ivory buttons (2017.11.1), and the cotton fisherman's sweater (2017.24.1), and the Nantucket Looms became an island establishment. The company was run by Oates and Euler until 1993 and continues today with a different aesthetic but a still active weaving workshop.

The Nantucket Looms was born out of an effort to promote the historic image of an island, but through the collective vision of Mary Anne Beinecke, Andy Oates, and Leslie and D.D. Tillett, historicism and modernism played equal parts in the craft revival on Nantucket. While on the surface, the island seems like a time capsule of its past, this story is just one of many that shows that Nantucket has more to offer than historicism, and more to its history than the whaling days.

Thank you to Julie Beinecke Stackpole, Seth Tillett, Karin Sheppard and Lia Marks for sharing with me their stories and insights into their families' involvement with the Nantucket Looms, and to the staff of the Nantucket Historical Association, especially Michael Harrison and Amelia Holmes, for their generous support, feedback, and assistance.

\section{Bibliography}

"An Interview with Andy Oates." Interview by Connie Bostic. Black Mountain College Museum + Arts Center, Asheville, NC, July 28, 2010. Video, 6min., 2 sec. https://www.blackmountaincollege.org/oral-histories/

Brown, Vivian (Associated Press). "Handcrafted look big in new American homes." Chippewa Falls, Wis: Herald-Telegram, April 23, 1965.

Chesrown, Melva A. "Nantucket Looms, Fabrics by Island Weavers in Restored Inn." Handweaver \& Craftsman, Fall 1963, 6-9.

"Cloth Company Inventories Sold," Inquirer \& Mirror, April 4, 1968. Nantucket Atheneum's Digital Historic Newspaper Archive.

Coffin, H. Errol. "The Jared Coffin House, Formerly the Ocean House.” Historic Nantucket, April 1962.

\footnotetext{
${ }^{31}$ The New York store was announced in Hammel, "A Fashionable Hint of the Sea Floats in From Nantucket" and "Nantucket Goods in New York's Newest Store," Inquirer \& Mirror, November 22, 1967, Nantucket Atheneum. The sale was announced in "Cloth Company Inventories Sold," Inquirer \& Mirror, April 4, 1968, Nantucket Atheneum's Digital Historic Newspaper Archive. Both Stackpole and Seth Tillett indicated that the Cloth Company's end and the Tilletts' departure was likely due, at least in part, to lack of economic success and Walter Beinecke's unwillingness to continue to invest in the company. Tillett also explained that his parents were already planning the Bedford Stuyvesant project in New York at this time. Stackpole, 68; Seth Tillett in conversation with the author.
} 
Fer, Briony. "Black Mountain College Exercises." In Anni Albers, edited by Ann Coxon, Briony

Fer, and Maria Müller-Schareck, 65-67. New Haven: Yale University Press, 2018.

Frances, Evan. "Classic Colonial, Nantucket Style.” Family Circle, May 1966.

Gough, Marion. "Those Unexpected Pleasures.” House Beautiful, November 1964.

Hammel, Lisa. "A Fashionable Hint of the Sea Floats in From Nantucket." New York Times, November 11, 1967. Proquest.

Hammel, Lisa. "The Nantucket Mood - in Fabric.” The New York Times, July 23, 1966. Proquest.

Hammel, Lisa. "New Line of Fabrics Is Woven on Nantucket." The New York Times, October 16, 1964. Proquest.

"Handlooms on Nantucket." American Fabrics, Fall 1965.

Hoffman, Marilyn. "Where Weavers Weave.” Christian Science Monitor, October 28, 1964. Proquest.

The Josef and Anni Albers Foundation. "Interaction of Color." Accessed January 18, 2021. https://albersfoundation.org/teaching/josef-albers/interaction-of-color/publications/.

Julie Beinecke Stackpole Collection on Mary Ann Beinecke, 1961-2018 (Ms.549). Nantucket Historical Association, Nantucket, MA.

Koven, Katie Lee. Black Mountain College: Shaping Craft + Design. Asheville, NC: Black Mountain College Museum + Arts Center, 2013.

Kriebel, Charles. "Nantucket Catch.” Home Furnishings Daily, August 25, 1967.

LaJoie, Raymond A. "Nantucket golden days." The Christian Science Monitor, May 9, 1967. Proquest.

Lia Marks and Karin Sheppard in conversation with the author, January 29, 2018, Nantucket, MA.

"Mary Ann Beinecke Decorative Art Collection," The Clark Art Institute, https://www.clarkart.edu/library/special-collections/mary-ann-beinecke-collection. Accessed January 21, 2021.

Mary Ann Beinecke Papers 1963-1975 (Ms.550). Nantucket Historical Association, Nantucket, MA.

"Nantucket Historical Trust Announces New Agreement for World-Wide Sale of Island Manufactured Fabrics.” Inquirer \& Mirror, May 28, 1964. Nantucket Atheneum's Digital Historic Newspaper Archive.

"Nantucket Goods in New York's Newest Store.” Inquirer \& Mirror, November 22, 1967. Nantucket Atheneum's Digital Historic Newspaper Archive.

"Nantucket Renaissance." Interior Design, January 1964.

"Nantucket Weavers Read to Try Their Skills in Many New Areas." Inquirer \& Mirror, January 2, 1964. Nantucket Atheneum's Digital Historic Newspaper Archive.

“New York Outfit Takes Over Looms," Inquirer \& Mirror, October 28, 1965. Nantucket Atheneum's Digital Historic Newspaper Archive.

Page, Marian. "The Jared Coffin House, fifth in Interiors' series on Historic Restorations." Interiors, January 1964.

Parry, Linda. William Morris Textiles. London: V\&A Publishing, 2013.

Pronesti, Jennifer. The Textile Designs of D.D. and Leslie Tillett, 1947-1979. MA Qualifying

Paper, Fashion Institute of Technology, 2019. Proquest.

"Ruggedness \& Elegance." House \& Garden, April 1966.

Seth Tillett in conversation with the author, August 10, 2020. 
Stackpole, Julie Beinecke. Mary Ann Beinecke's Nantucket Textile Renaissance, a History and a Memoire, by her daughter. Julie Beinecke Stackpole, 2018.

"Travel \& Study: Nantucket Looms." Craft Horizons, May 1, 1965.

Troy, Virginia. The Modernist Textile Europe and America 1890-1940. Aldershot: Lund Humphries, 2006.

"Vogue's Decorating Finds and Ideas for Fashions in Living: The Tilletts at Nantucket... decorating scoop U.S.A.” Vogue, May 1, 1967. Proquest.

"Walter Beinecke's Fight For Nantucket: Buying up an Island for Its Own Good." LIFE, September 6, 1968. Google Books.

Ward, Susan. "The Design, Promotion, and Production of Modern Textiles in the USA, 194060.” In Knoll Textiles, edited by Earl Martin, 36-72. New Haven: Published for Bard Graduate Center by Yale University Press, 2011.

Yates, Margaret. "Summer Seasoning." Inquirer \& Mirror, August 4, 1966. Nantucket Atheneum's Digital Historic Newspaper Archive. 